p-ISSN 0044-1600

e-ISSN 2392-3458

Zagadnienia Ekonomiki Rolnej

www.zer.waw.pl

$3(352) 2017,146-163$

JAN PAWLAK

DOI: $10.30858 /$ zer/83038

Institute of Technology and Life Sciences

Warsaw Department

\title{
EQUIPMENT WITH DRAFT FORCE AND LABOUR PRODUCTIVITY IN THE POLISH AGRICULTURE
}

\begin{abstract}
The paper presents an analysis of correlations between equipment with draft force and labour productivity in agriculture. Between 1950 and 2010 live and mechanical draft force resources in the Polish agriculture increased by $365.7 \%$, of that the mechanical one 65 times. At the same time, the number of persons working in Polish agriculture decreased by more than $37 \%$, while the value of agricultural product in fixed prices increased: for gross output by $98 \%$, final output - by 156\%, and market output - by $280 \%$. Labour productivity in agriculture (value of production in fixed prices per capita working in agriculture) increased, in the case of adoption as a measure of this production: gross output - by $216 \%$, final output - by $305 \%$, and market output - by 506\%. Strongly marked positive correlation between equipment with draft force and labour productivity in agriculture has been found. The strength of this correlation weakened along with increasing equipment of agriculture with draft force.
\end{abstract}

Keywords: labour productivity, draft force, correlation, agriculture.

JEL codes: D33, J24, Q10.

\section{Introduction}

In conditions typical for market economy countries, and in the light of the tendency for deterioration of relations between labour costs and agricultural inputs' prices and sales prices of agricultural products, drawing income from farms, at least at the parity level, requires an improved effectiveness of using production factors, measured by productivity of land, labour and capital (Ziętara, 1998), 
and it creates the need for increasing the scale of production on farms supplying to the market. In conditions of limited demand for agricultural products, the primary way of increasing the scale of production is to expand the area of farms. Increasing the area of farms is one of the factors enhancing the effectiveness of inputs in agricultural production (Sheng, Davidson, Fuglie and Zhang, 2016). The area of a parity farm in Poland raises. In 1990, farmers could generate parity income from a farm with the area of 10 hectares of agricultural land. In 2005, the area of parity farms already ranged between 20 and 35 hectares of agricultural land (Ziętara, 2009a, b). The minimum area of agricultural land ensuring competitiveness ${ }^{1}$ of Polish farms, studied under Polish and European FADN in 2010-2012, amounted to 110 hectares (Ziętara and Zieliński, 2016).

Low economic labour productivity in Polish agriculture, expressed as value of production per one employed person, is a serious problem. In 1990, labour productivity in agriculture was ca. 4 times lower than in non-agricultural sectors, while in 1998 it was already 6.5 times lower (Ziętara, 2000). On Polish farms under research, labour productivity was similar to that achieved for Czech, Slovak and Hungarian farms, but more than two times lower than in Germany. Labour productivity increases with the increase of economic size of farms (Ziętara and Zieliński, 2016).

The increasing environment protection requirements may be a barrier hindering growth of labour productivity on farms. This is confirmed by farms, which met the requirements related to retention of adequate level of soil fertility. Labour effectiveness, measured by the relation between family income and work load, was relatively low in 45 farms, studied in 2009-2010, with a balanced level of renewal of soil organic matter, amounting on average to PLN 15.2 per manhour $^{-1}$, with the lowest value (PLN 10.0 per man-hour ${ }^{-1}$ ) recorded in a group of farms with the highest level of organic matter renewal (Sawa and Kocira, 2013).

Wójcicki (2014) drew attention to the need for research on technological and economical transformations on farms. The research of Wójcicki, Pawlak and Rudeńska (2014) has shown a correlation between the value of agricultural production in the form of gross margin and the replacement value of agricultural equipment on family farms. On the basis of own research, Kocira (2008) found that the value of gross margin on farms depends on the condition of technical equipment.

In a longer perspective, the conditions of functioning of Polish agriculture continued to change, which was expressed through a decreasing area of land used and a decreasing number of persons working in agriculture, with simultaneous increase in the level of mechanisation and motorisation of agriculture, which was reflected in increased resources of draft force and increased share of mechanical power in its structure. These changes had an impact on the level of labour productivity in agriculture. The attempt to define the strength of this

\footnotetext{
${ }^{1}$ Competitiveness (capacity to develop) of studied farms has been defined through a competitiveness ratio, which illustrates the relation between income from a farm and total cost of use of own inputs (labour, land, capital).
} 
impact was the motivation behind this paper. Its objective is to analyse correlations between availability of draft force and labour productivity in Polish agriculture. The research spans over 60 years (1950-2010).

\section{Research material and methodology}

While pursuing the objective of work outlined above, the author used materials from GUS publications (1966, 1971, 1976, 1978, 1982, 1987, 1992, 1994, 1999, 2002, 2005, 2006, 2007, 2008, 2010, 2011a, b, 2012, 2013, 2014, 2015, 2016). This formed grounds to analyse changes in labour resources, changes in the value of agricultural production and quantitative changes in availability of draft force in the Polish agriculture in 1950-2013. The methodology for the collection and analysis of data on the status of draft force and the value of selected categories of production in Polish agriculture in constant prices, was described by Pawlak (2016).

The literature on the subject presented different definitions of labour productivity in agriculture, e.g. economic labour effectiveness, measured through the value of production per one employed person (Ziętara, 2009a), and technical labour productivity, measured through the quantity of production from 1 hectare per 1 hour of own and external labour (Skarżyńska, 2017). In this paper, labour productivity in individual years of the period under analysis was calculated in line with the definition given by Ziętara, using the following formula:

$$
E w p_{k r}=\frac{P_{k r s}}{N p_{k r}}
$$

where:

$E w p_{k r}$ - labour productivity in year $\mathrm{r}$, measured through the value of agricultural production category $\mathrm{k}$ (PLN thousand/person ${ }^{-1}$ );

$P_{k r s} \quad$ - value of agricultural production category $k$ in year $r$, in constant prices (PLN million;

$N p_{k r} \quad$ - number of persons working in agriculture in year $r$ (thousand persons).

An analysis of economic processes in longer periods of time requires comparability of entry data throughout the entire period under analysis. In the case of research on changes in labour productivity in agriculture, the data on labour resources in agriculture are of primary importance. The Central Statistical Office (Główny Urząd Statystyczny, GUS) publications mentioned above have been used as data source for this study. However, in the course of data analysis, a problem was identified, namely different measures of labour resources were used in GUS publications from different years: references were made to persons economically active ${ }^{2}$, working and employed in agriculture. In a study by GUS

\footnotetext{
${ }^{2}$ Persons economically active in agriculture are "persons performing work bringing pay or income irrespec-
} 
(1966), estimated data were provided on the number of persons economically active in agriculture in 1950 and in 1960. In a later GUS publication (GUS, 1971), data were available on the number of persons employed in agriculture (full-time and full-time equivalent) in 1965-1969. In subsequent agricultural yearbooks (GUS, 1982, 1987, 1992), these persons were already referred to as working in agriculture. Since that time, only persons employed on the basis of employment contract were included in the "employed in agriculture" category. In some GUS publications $(1987,1992)$ also the number of persons economically active in agriculture in 1970, 1978, 1984 and 1988 was given. GUS data on the number of persons working in different periods are incomparable due to changes in the methodology of research. In a publication from 2005, the data on the number of persons working in 2002 were provided in two versions. One of them (2109.0 thousand persons) was determined in line with the methodology in place at the time, the second (4229.4 thousand persons) was similar to data from the general agricultural census in 1996. Furthermore, there were differences regarding persons included in the category of working in agriculture between 2002-2009 and 2010-2013. In the first of these periods, as a result of exclusions of certain groups of persons, the numbers of persons working in agriculture given by GUS were lower than in 2010 and in subsequent years.

In this situation, estimations were necessary, ensuring comparability of data on the number of persons working in agriculture throughout the period under analysis. On the basis of data on those economically active and working in agriculture in 1970, 1978, 1984 and 1988, the average value of an indicator for these years was determined, expressing the quotient of the number of persons working in agriculture and the number of those economically active in agriculture. The value of this indicator is 0.92 . Then, by multiplying the number of persons economically active in agriculture in 1950 and 1960 by the value of the indicator, the estimated number of persons working in agriculture in these years was determined.

The data on the number of persons working in agriculture in 2002 was adopted in the value comparable with that of 1996, while for 2010 the values were calculated by multiplying the value provided in the GUS agricultural yearbook (2016) by coefficient 1.75 , calculated on the basis of data from the aforementioned yearbook (GUS, 2005), where additional numbers comparable to the status from 1996 were provided, as well on the basis of information on the scope of persons included in the category of working in agriculture in 2002-2009 and 2010-2013. The numbers of persons working in agriculture in 1951-1959, 1961-1969, 1971-1979, 1986-1995, 1997-2001 and 2003-2009, respectively, have been determined by interpolation.

The correlation between the availability of draft force in agriculture and labour productivity was presented in a graphic form with determination of models of functions, describing them with the highest coefficient of determination R2.

tive of a place and duration of work, i.e. all persons working or temporarily not working' (GUS, 1982). 
The analysis of correlations between researched variables over a long period of time makes the accuracy of cognition of researched phenomenon limited, due to the necessity to apply estimates of levels of variables, different methodologies of calculation in different periods, as well as specific attributes of individual periods (e.g. stability of agricultural prices in certain periods of former political system). Furthermore, in the period under analysis, not only the draft force effort and proportions between live and mechanical draft force changed, but also other inputs, particularly of industrial origin. This was accompanied by a continuous progress in many areas (including biology, agricultural technology, animal science, organisation).

\section{Results and analysis}

In 1950-2010, the number of persons working in agriculture decreased by more than $37 \%$. Over the same period, the global production of agriculture increased by $98 \%$. As a result, labour productivity in agriculture, measured by the value of final production in constant prices per one employed person, increased by $216 \%$ over the period.

Increased agricultural production in a situation, when the area of land cultivated in Poland was decreasing, was possible thanks to biological and technological progress, reflected among others by availability of draft force. In the period covered by this analysis, the resources of draft force (live and mechanical) in Polish agriculture increased by $365.7 \%$ (Fig. 1).

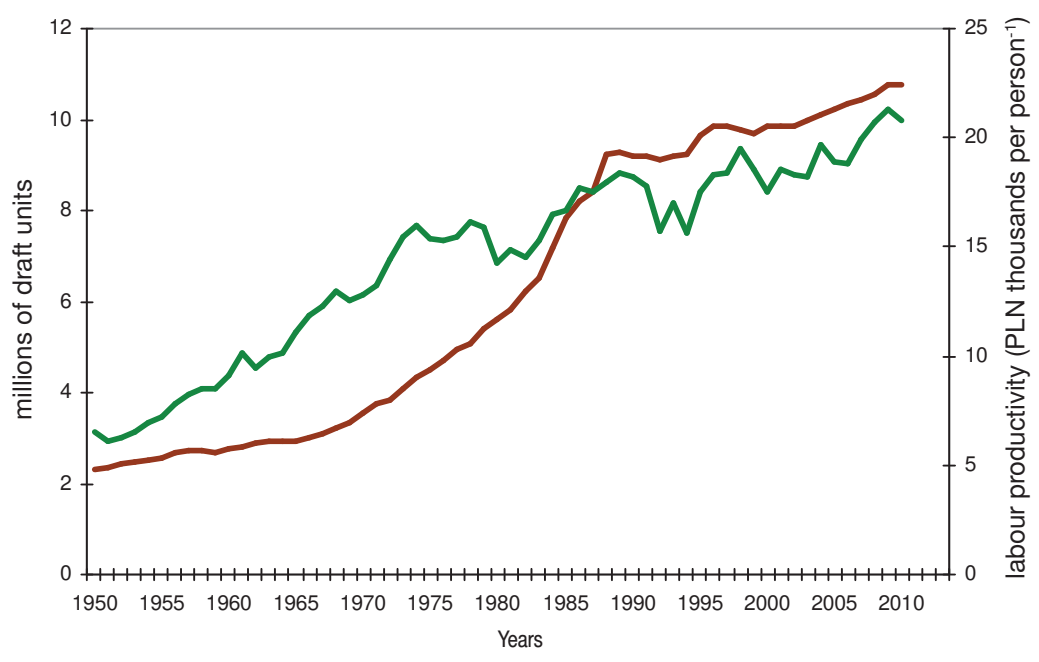

- Draft force - Global production per person

Fig. 1. Availability of live an mechanical draft force and labour productivity measured by the value of global production in constant prices per person working in agriculture.

Source: own study on the basis of GUS data $(1966,1971,1976,1978,1982,1987,1992,1994,1999$, 2002, 2005, 2006, 2007, 2008, 2010, 2011a, b, 2012, 2013, 2014, 2015, 2016). 
In 1950-2010 the final production of agriculture increased by $156 \%$, while labour productivity in agriculture, measured by the value of final production in constant prices per one employed person, increased by $305 \%$ over the same period (Fig. 2).

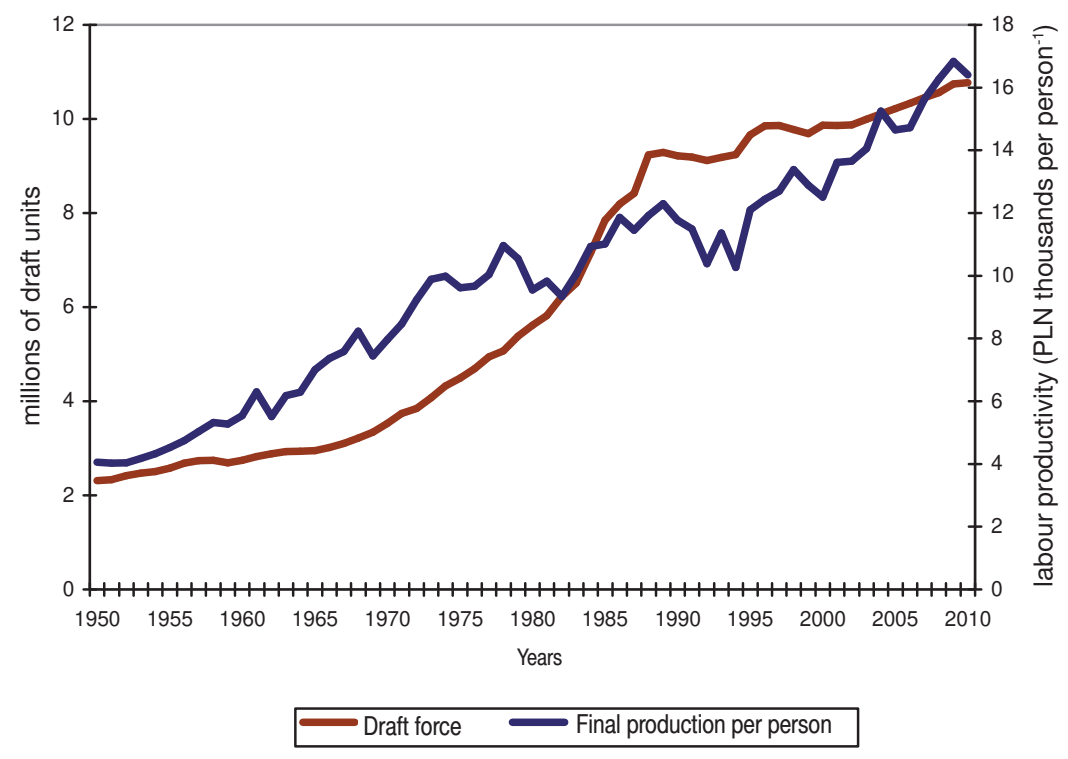

Fig. 2. Availability of live an mechanical draft force and labour productivity measured by the value of final production in constant prices per person working in agriculture.

Source: as for Fig. 1.

In the period under analysis, the market production of agriculture increased by $280 \%$, while labour productivity in agriculture, measured by the value of market production in constant price terms per one employed person, increased by $506 \%$ (Fig. 3).

In 2010, the resources of mechanical draft force in the Polish agriculture were 65 times larger than in 1950. Roughly until the end of 1980s, the dynamics of growth in this type of draft force was higher than for labour productivity measured by the value of global production in constant prices per person working in agriculture (Fig. 4). The growth of the number of units of draft force, compared to preceding years, was getting systematically lower with the increase of the number of units of mechanical draft force in agriculture. In comparison to 1949, the number of such units was $27.3 \%$ higher in 1950, while in 2010 it was only $0.3 \%$ higher than in the preceding year.

As regards labour productivity measured by the value of global production in constant prices per person working in agriculture, both increases and decreases of production level were recorded in subsequent years. The maximum increase in relation to the preceding year (by 12.2\%) was recorded in 1995, while the largest decrease (by 11.0\%) in 1981. 


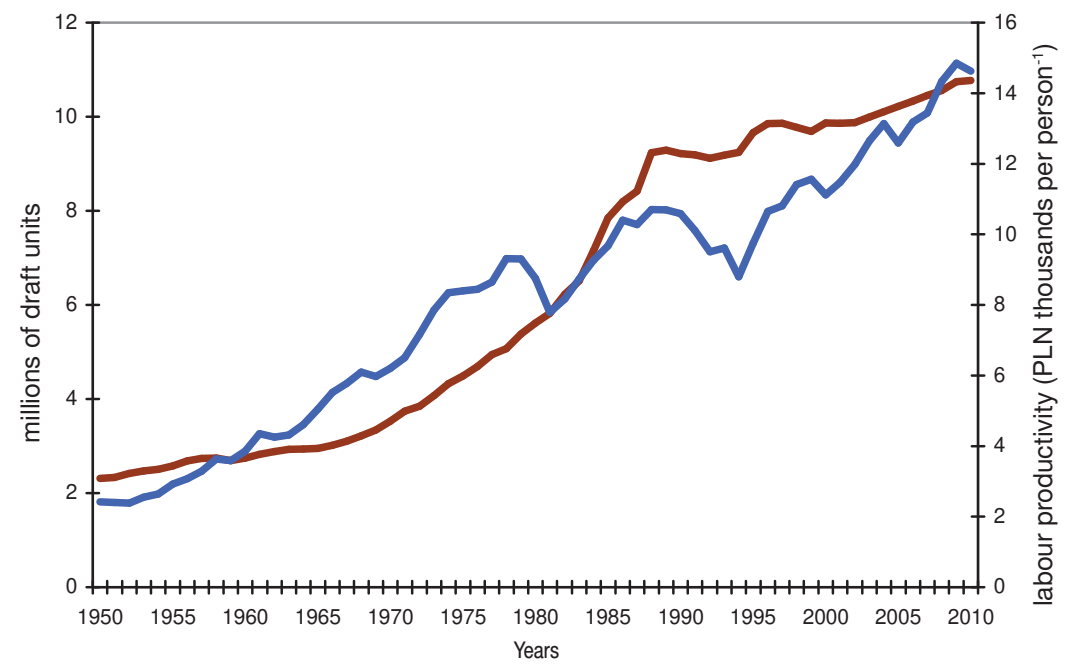

Draft force Market production per person

Fig. 3. Availability of live and mechanical draft force and labour productivity measured by the value of market production in constant prices per person working in agriculture.

Source: as for Fig. 1.

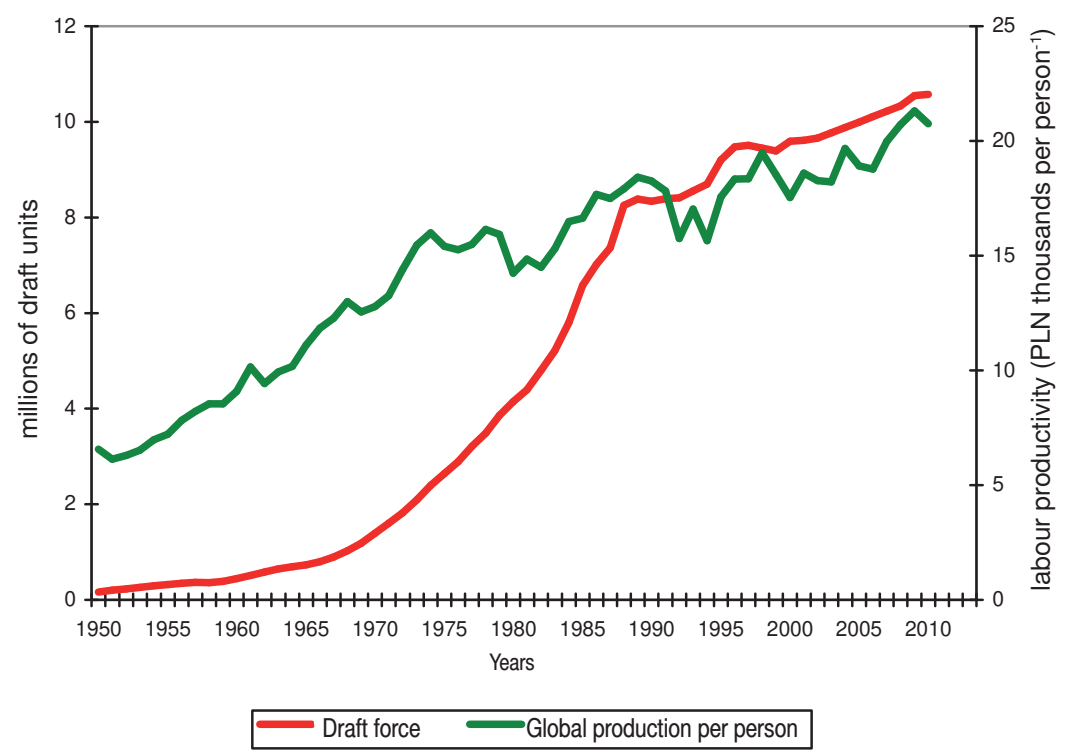

Fig. 4. Availability of mechanical draft force and labour productivity measured by the value of global production in constant prices per person working in agriculture.

Source: as for Fig. 1. 
Labour productivity measured by the value of final production in constant prices per person working in agriculture fluctuated over subsequent years. The maximum increase in relation to the preceding year (by 17.9\%) was recorded in 1995, while the largest decrease (by 12.5\%) was recorded in 1962 (Fig. 5).

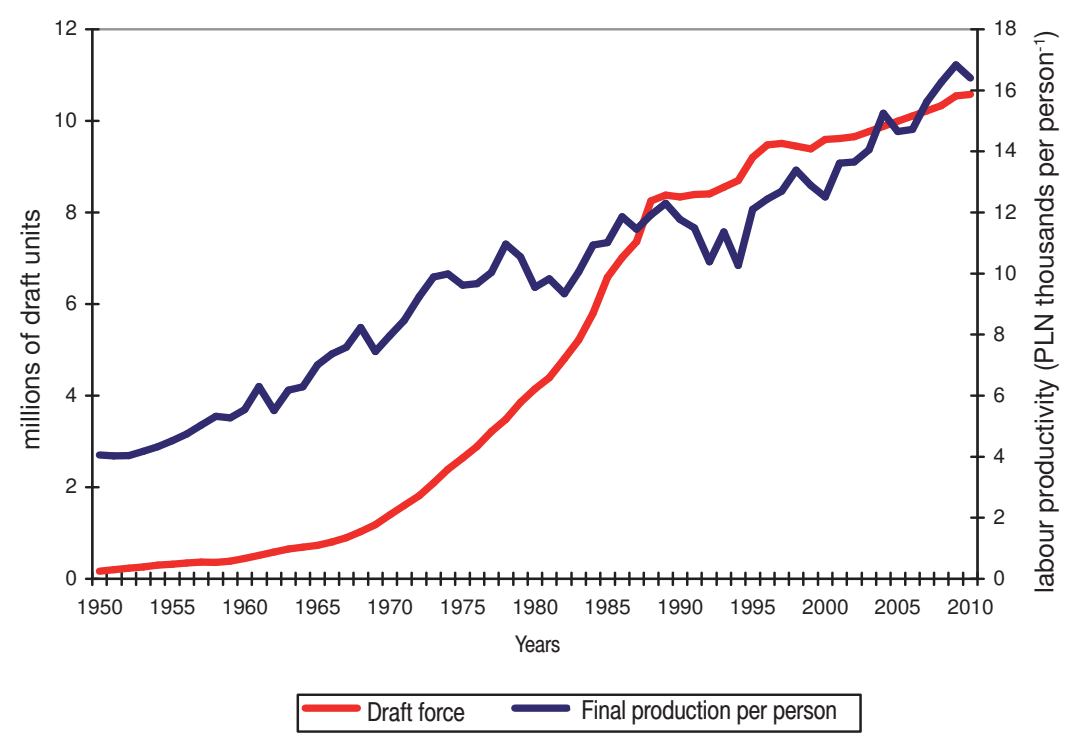

Fig. 5. Availability of mechanical draft force and labour productivity measured by the value of final production in constant prices per person working in agriculture.

Source: as for Fig. 1.

Also labour productivity, measured by the value of market production in constant prices per person working in agriculture, fluctuated substantially over subsequent years. The maximum increase in relation to the preceding year (by $12.9 \%$ ) was recorded in 1961, while the largest decrease (by 11.0\%) was recorded in 1981 (Fig. 6). High volatility of the level of labour productivity resulted from fluctuations of values in individual categories of agricultural production. One of the factors influencing changes of agricultural production levels were weather conditions in individual years. Overwintering of winter crops depends on temperature and snow cover in winter periods, while the conditions for development of crops depend on the level of precipitation, its distribution over the year, and water resources in soil. These factors have affected yields and indirectly - the value of agricultural production and labour productivity in agriculture in individual years. In an analysis using current prices, decreasing yields in individual years do not necessarily mean decreased value of production, as they may be accompanied by increased prices. However, the use of constant prices in this analysis results in a situation, where weather conditions did have an impact on the value of agricultural production in individual years. 


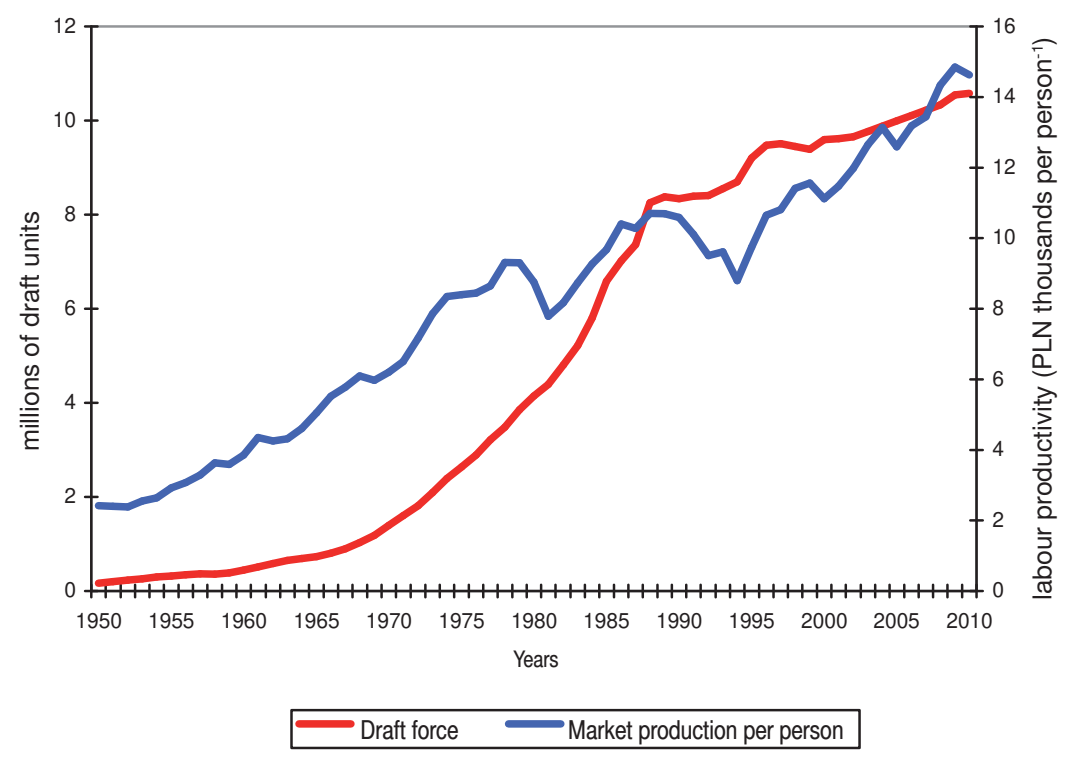

Fig. 6. Availability of mechanical draft force and labour productivity measured by the value of market production in constant prices per person working in agriculture.

Source: as for Fig. 1.

The correlation between availability of draft force (live an mechanical) and labour productivity, measured by the value of global production in constant prices per person working in agriculture, is well described by a logarithmic function (Fig. 7). However, the strength of this correlation weakens with higher values of draft force. The value of the coefficient of determination R2 of the same function for the value not exceeding 5.5 million units of draft force (1950-1979) equals 0.92 , while for the value above 5.5 million units of draft force (1980-2010) - is only 0.72 . This is because in the conditions of relative saturation of agriculture with draft force ${ }^{3}$ and its decreasing use, further increase of agricultural production is to an growing extent conditioned by biological progress and improvement of cultivation, fertilisation and plant protection methods, as well as organisation of work, the significance of which raises when better, but more and more expensive, agricultural equipment is used. Moreover, the decrease in intensity of the correlation with higher values of draft force units also results from the law of diminishing returns.

The same type of function also serves well to describe the correlation between availability of live and mechanical draft force and labour productivity,

\footnotetext{
${ }^{3}$ Numerical values are not sufficient to assess qualitative condition of draft force resources in agriculture. Some of already depreciated tractors are still used in farms for certain activities, being permanently aggregated with - for example - a fodder wagon, loader, etc. Presence of such a tractor does not mean excessive availability of draft force.
} 
measured by the value of final production in constant prices per person working in agriculture (Fig. 8). Also in this case, the strength of such correlation weakens with increasing endowment of agriculture with draft force.

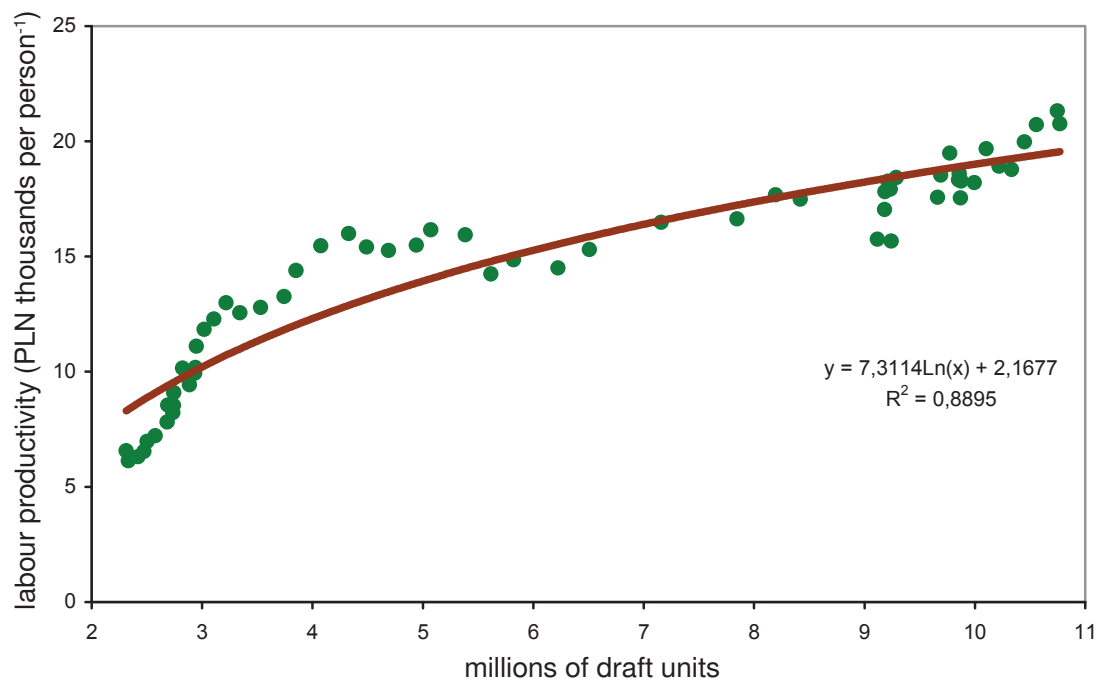

Fig. 7. Availability of live an mechanical draft force and labour productivity measured by the value of global production in constant prices per person working in agriculture.

Source: as for Fig. 1.

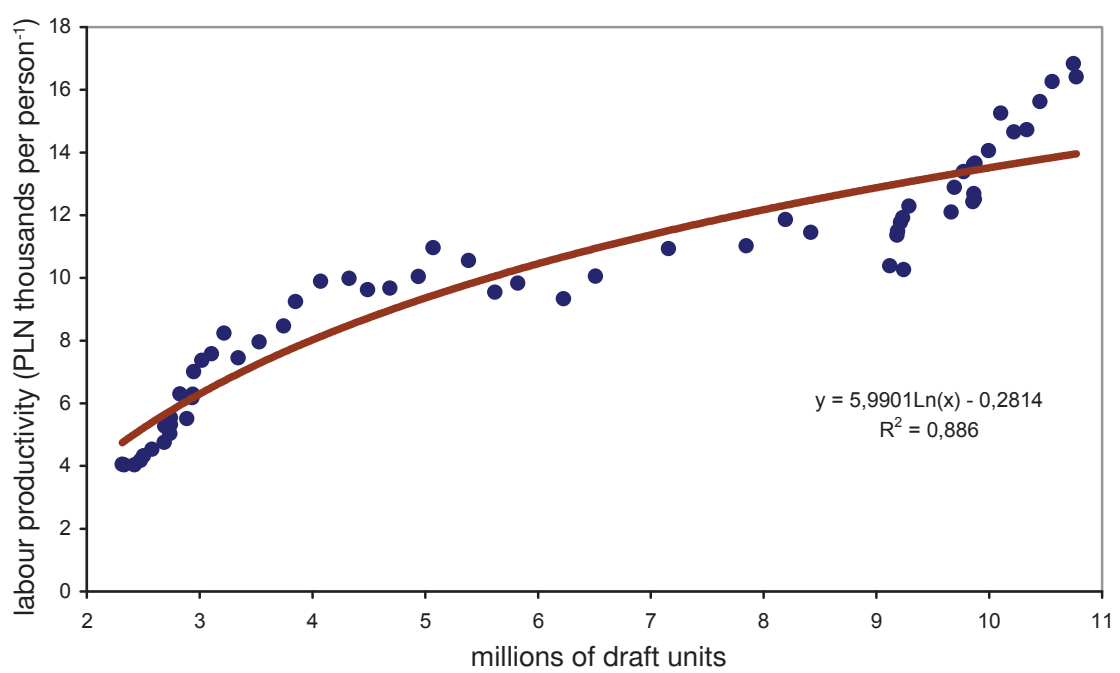

Fig. 8. Availability of live an mechanical draft force and labour productivity measured by the value of final production in constant prices per person working in agriculture.

Source: as for Fig. 1. 
It should be noted that the very draft force does not cause increased productivity of plants, but thanks to facilitating production activities at the right times, it prevents decreases in agricultural production caused by decreasing yields, e.g. because the best time for sawing or plant protection treatments was not observed or late harvesting of plants caused losses. The draft force is also a factor supporting the workforce and other inputs in the production process and is their valuable substitute, which had been noted years ago by Professor Zenon Kierul.

The correlation between availability of draft force (live and mechanical) and labour productivity, measured by the value of market production in constant prices per person working in agriculture, is well described by a polynomial function (Fig. 9).

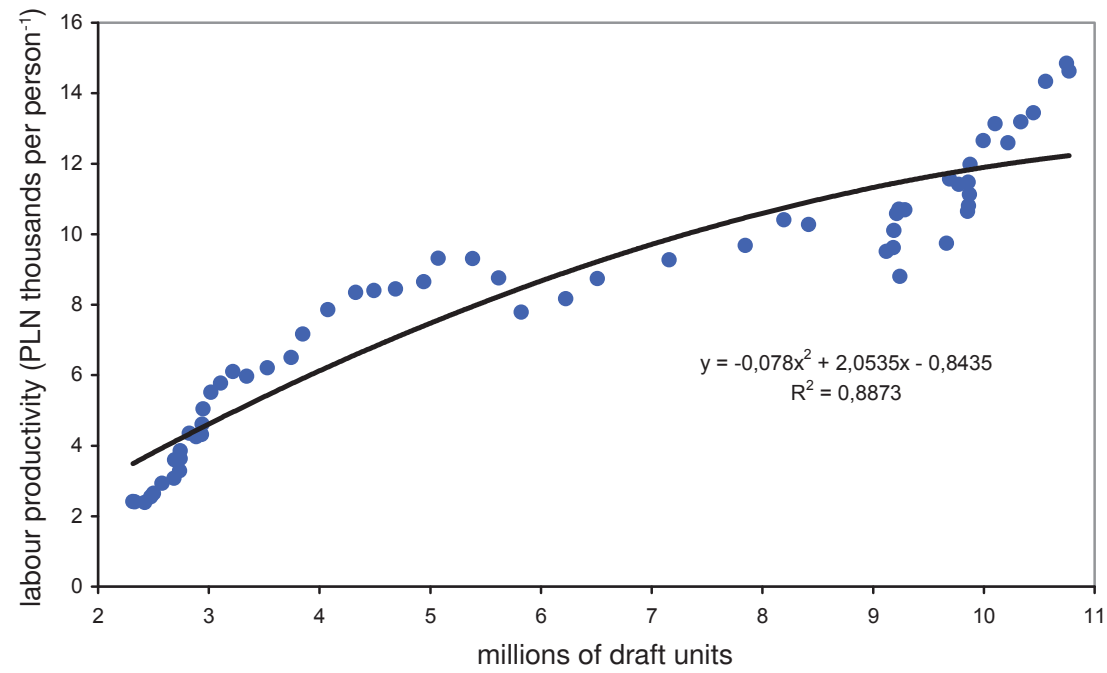

Fig. 9. Availability of live and mechanical draft force and labour productivity measured by the value of market production in constant prices per person working in agriculture.

Source: as for Fig. 1.

There is also a positive correlation between availability of mechanical draft force and labour productivity in agriculture, with the strength of respective correlations in this case stronger than in the case, where total resources of live and mechanical draft force were the point of reference for labour productivity (Fig. 7, 8 and 9). The use of mechanical draft force is connected with a higher level of mechanisation of production processes in agriculture. It should be noted though that the correlation under research, where only the mechanical draft force that is adopted as the benchmark, is also influenced by the fact that in a situation, where the resources of mechanical draft force are the reference point, the value of denominator - with the same numerator - is lower than in the 
case of using the total draft force (live and mechanical). Moreover, in the period under analysis, changes in the draft force structure were taking place at a different pace (initially, there was proportionally more live draft force than at the end of the researched period).

Also in this case, the strength of such correlation weakens with increasing endowment of agriculture with draft force. The value of the coefficient of determination R2 of the logarithmic function describing correlation between availability of mechanical draft force and labour productivity, measured by the value of global production in constant prices per person working in agriculture, for the value not exceeding 4 million units of mechanical draft force (1950-1979) is 0.97 and for the value above 4 million units of mechanical draft force (1980-2010 ) - it is only 0.71 .

The correlation between availability of mechanical draft force in the entire period under analysis and labour productivity, measured by the value of global production in constant prices per person working in agriculture, is very well described by a logarithmic function (Fig. 10).

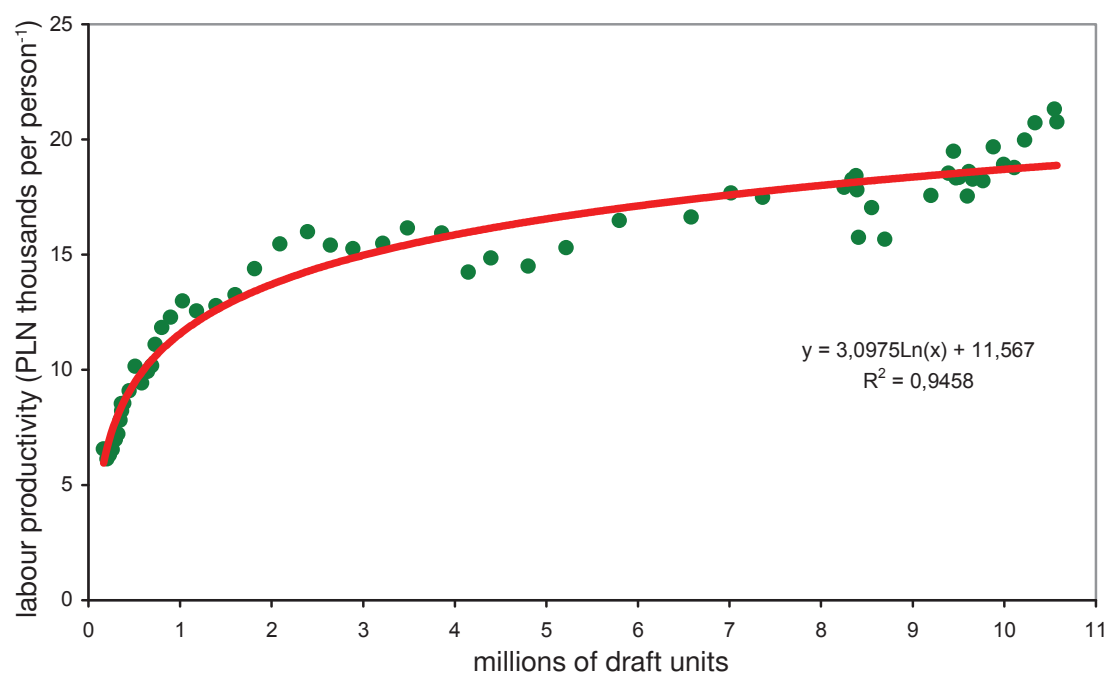

Fig. 10. Availability of mechanical draft force and labour productivity measured by the value of global production in constant prices per person working in agriculture.

Source: as for Fig. 1.

An equally high value of coefficient of determination characterises the logarithmic function describing the correlation between availability of mechanical draft force and labour productivity, measured by the value of final production in constant prices per person working in agriculture (Fig. 11). 


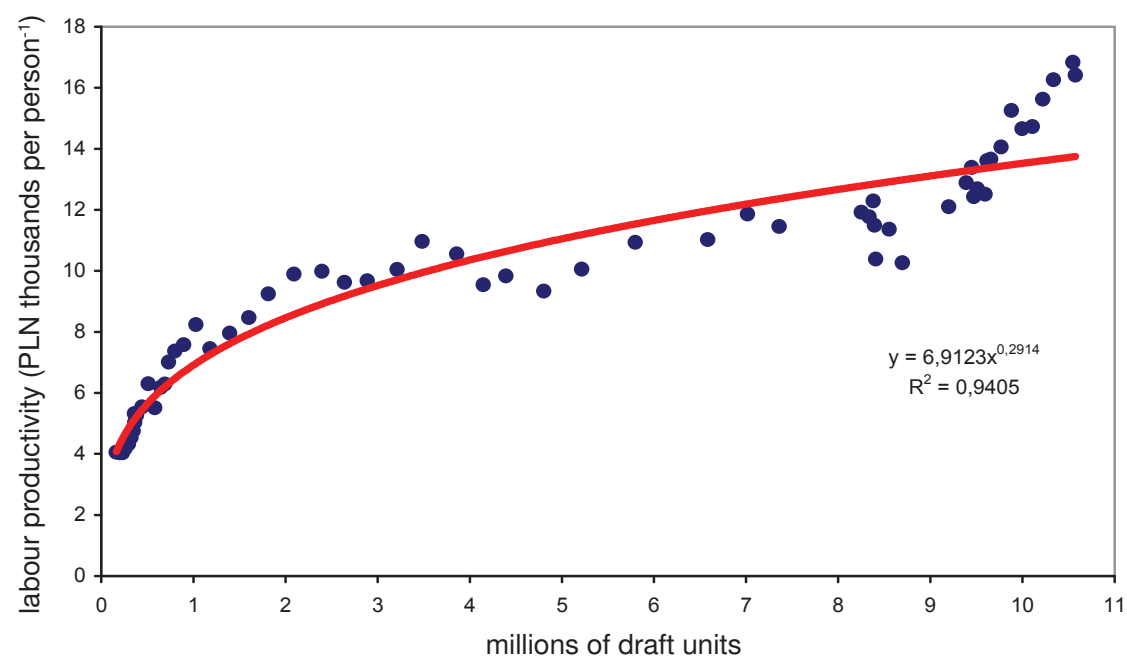

Fig. 11. Availability of mechanical draft force and labour productivity measured by the value of final production in constant prices per person working in agriculture.

Source: as for Fig. 1.

The correlation between availability of mechanical draft force and labour productivity is the strongest when the productivity is measured by the value of market production in constant prices per person working in agriculture (Fig. 12).

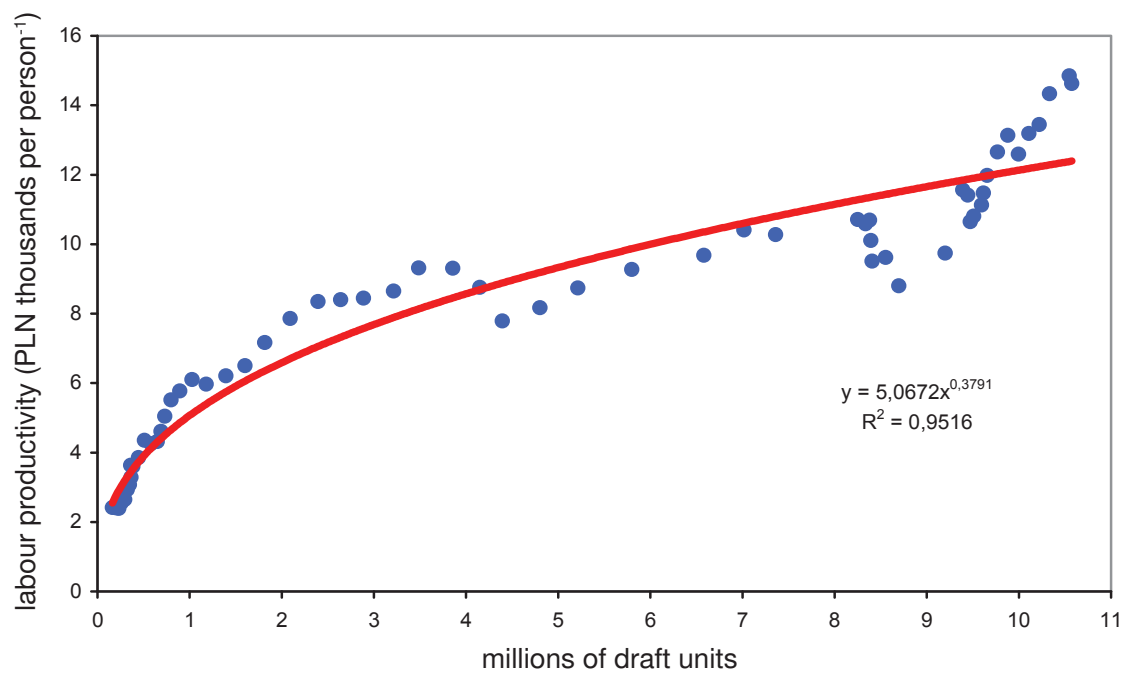

Fig. 12. Availability of mechanical draft force and labour productivity measured by the value of market production in constant prices per person working in agriculture.

Source: as for Fig. 1. 
Availability of draft force in agriculture and the share of mechanical power in its structure reflect the status of its mechanisation. The status of mechanical draft force reflects the level of motorisation of agriculture. The strong correlation between this availability and labour productivity confirms the results of research carried out earlier, which had shown that increased capital-labour ratio enhances labour productivity. However, their role kept changing over the sixty years covered by the analysis. In the beginning of this period, it consisted primarily in substituting "live" work with mechanical one, represented by agricultural mechanical equipment. This process contributed to the timeliness of work and to reduction of losses in the course of harvesting and storage of products. In Poland, mechanisation initially covered farms referred to as "social", but with time - also individual farms.

The progress in agricultural engineering improves the effectiveness of production inputs, while respecting the requirements of environmental protection. Improved design of agricultural machinery facilitates increased productivity, as well as reduction of unit energy outputs and harmful emissions. Reduction of environmental burden is enhanced by rational and reasonable use of machinery, from the moment of design, through operation to recycling. The research carried out in the Institute of Agricultural Engineering and Informatics of the University of Agriculture in Cracow has shown that the level of the capital-labour ratio and the indicators of scientific and technological progress are clearly positively correlated with labour productivity (Michałek and Grotkiewicz, 2009).

The general tendency, seen also in agriculture, is characterised by gradually diminishing role (in relative terms) of material inputs (Bernardini and Galli, 1993). On the other hand, the role of information continues to grow. In modern agriculture, accurate information is one of the fundamental conditions for achieving high effectiveness of inputs on farms. Farmers should have access to up-to-date, reliable and as complete as possible information on market situation, inputs, as well as biological, technical and technological progress. They also must have access to current data on what is going on in their farms (for example condition of plants and spatial distribution of crops, changes to environment, threats from diseases, pests or weeds, etc.). This implies the need for supplying agricultural equipment with devices facilitating collection of such data.

\section{Summary}

In 2010, the resources of mechanical draft force in Polish agriculture were 65 times larger than in 1950. Roughly, until the end of the 1980s, the dynamics of growth of this type of draft force was higher than for labour productivity, measured by the value of global production in constant prices per person working in agriculture.

A strong positive correlation exists between availability of draft force and labour productivity in agriculture. If only the mechanical draft force is adopted as 
the benchmark, this correlation is clearer than in a situation when the total draft force (live and mechanical) is adopted as the benchmark. The use of mechanical draft force is connected with a higher level of mechanisation of production processes in agriculture. It should be noted though that the correlation under research, if only the mechanical draft force is adopted as the benchmark, is also influenced by the fact that in a situation, where the resources of mechanical draft force are the reference point, the value of denominator - with the same numerator - is lower than in the case of using the total draft force (live and mechanical).

The strength of this correlation weakens with increasing endowment of agriculture with draft force, which is the result of relative saturation of agriculture with draft force and its decreasing use, but also results from the law of diminishing returns. Moreover, increased agricultural production is to an increasingly growing extent conditioned by biological progress and improvement of cultivation, fertilisation and plant protection methods, as well as organisation of work, the significance of which increases when better, but more and more expensive agricultural equipment is used. Availability of draft force is only one of many factors influencing labour productivity in agriculture.

The correlation between availability of mechanical draft force and labour productivity is strongest when the productivity is measured by the value of market production in constant prices per person working in agriculture. 


\section{References}

Bernardini, O., Galli, R. (1993). Dematerialisation: long-term trends in the intensity of use of materials and energy. Futures, vol. 25, no. 4, pp. 431-448.

GUS (1966). Rolniczy Rocznik Statystyczny 1945-1965. Warszawa, pp. 525.

GUS (1971). Rocznik Statystyczny Rolnictwa 1971. Warszawa, pp. 380.

GUS (1976). Rocznik Statystyczny 1976. Warszawa, pp. 632.

GUS (1978). Rocznik statystyczny rolnictwa i gospodarki żywnościowej 1978. Warszawa, pp. 516.

GUS (1982). Rocznik statystyczny rolnictwa i gospodarki żywnościowej 1982. Warszawa, pp. 436.

GUS (1987). Rocznik statystyczny rolnictwa i gospodarki żywnościowej 1986. Warszawa, pp. 431.

GUS (1992). Rolnictwo i gospodarka żywnościowa 1986-1990. Warszawa, pp. 399.

GUS (1994). Rocznik Statystyczny Rolnictwa 1993. Warszawa, pp. 373.

GUS (1999). Rocznik Statystyczny Rolnictwa 1998. Warszawa, pp. 481.

GUS (2002). Rocznik Statystyczny Rolnictwa 2001. Warszawa, pp. 315. ISSN 1508-0013.

GUS (2005). Rocznik statystyczny rolnictwa i obszarów wiejskich 2005. Warszawa, pp. 485.

GUS (2006). Rocznik statystyczny rolnictwa i obszarów wiejskich 2006. Warszawa, pp. 489.

GUS (2007). Rocznik statystyczny rolnictwa i obszarów wiejskich 2007. Warszawa, pp. 473.

GUS (2008). Rocznik statystyczny rolnictwa i obszarów wiejskich 2008. Warszawa, pp. 493.

GUS (2010). Rocznik Statystyczny Rolnictwa 2010. Warszawa, pp. 389.

GUS (2011a). Rocznik Statystyczny Rolnictwa 2011. Warszawa, pp. 393.

GUS (2011b). Środki produkcji w rolnictwie. Powszechny Spis Rolny 2010. Warszawa, pp. 111.

GUS (2012). Pracujacy w gospodarstwach rolnych. Powszechny Spis Rolny 2010. Warszawa, pp. 188.

GUS (2013). Rocznik Statystyczny Rolnictwa 2013. Warszawa, pp. 417.

GUS (2014). Rocznik Statystyczny rolnictwa 2014. Warszawa, pp. 445.

GUS (2015). Rocznik Statystyczny rolnictwa 2015. Warszawa, pp. 456.

GUS (2016). Rocznik Statystyczny rolnictwa 2016. Warszawa, pp. 456.

Kocira, S. (2008). Wpływ technicznego uzbrojenia procesu pracy na nadwyżkę bezpośrednią w gospodarstwach rodzinnych. Inżynieria Rolnicza, no. 4(102), pp. 375-380.

Michałek, R, Grotkiewicz, K. (2009). Postęp naukowo-techniczny a wydajność ziemi i pracy w wybranych regionach Polski. Problemy Inżynierii Rolniczej, no. 2(64), pp. 25-32.

Michałek, R., Tomczyk, W. (2002). Problemy eksploatacji maszyn i urządzeń w aspekcie ochrony środowiska. Problemy Inżynierii Rolniczej, no. 4(38), pp. 5-10.

Pawlak, J. (2016). Relacje wolumenu produkcji do zasobów siły pociągowej w rolnictwie polskim. Zagadnienia Ekonomiki Rolnej, no. 4(349), pp. 122-137.

Sawa, J., Kocira, S. (2013). Efektywność pracy w gospodarstwach o zbilansowanej odnawialności substancji organicznej. Problemy Inżynierii Rolniczej, no. 2, pp. 11-20.

Sheng, Y., Davidson, A., Fuglie, K., Zhang, D. (2016). Input substitution, productivity performance and farm size. The Australian Journal of Agricultural and Resource Economics, vol. 60 , ipp. 3 , p. 327-347. 
Skarżyńska, A., (2017). Efektywność techniczna, ekonomiczna i środowiskowa produkcji wybranych produktów roślinnych $\mathrm{w}$ regionach rolniczych Polski. Zagadnienia Ekonomiki Rolnej, no. 1(350), pp. 117-137.

Wójcicki,Z. (2014). Analiza potrzeb i możliwości inwestycyjnych gospodarstw rodzinnych. Problemy Inżynierii Rolniczej, no. 1(83), pp. 5-20.

Wójcicki, Z., Pawlak, J., Rudeńska, B. (2014). Wartości zestawów maszyn w badanych gospodarstwach rodzinnych. Problemy Inżynierii Rolniczej, no. 3(85), pp. 5-18.

Ziętara, W. (1998). Metodyczne aspekty oceny efektywności gospodarowania w rolnictwie. Zeszyty Naukowe SGGW. Ekonomika i organizacja gospodarki żywnościowej, no. 34(1998), pp. 17-32.

Ziętara, W. (2000). Ekonomiczna i społeczna wydajność pracy w różnych typach gospodarstw rolniczych. Zeszyty Naukowe SGGW. Ekonomika i organizacja gospodarki żywnościowej, no. 41, pp. 19-34.

Ziętara, W. (2009a). Model polskiego rolnictwa wobec aktualnych wyzwań.Zeszyty Naukowe $S G G W$. Ekonomika i organizacja gospodarki żywnościowej, no. 73, pp. 5-21.

Ziętara, W. (2009b). Uwarunkowania rozwoju gospodarstw wielkoobszarowych w Polsce. Stowarzyszenie Ekonomistów Rolnictwa i Agrobiznesu. Zeszyty Naukowe, t. XI, issue 1, pp. 490-495.

Ziętara, W., Zieliński, M. (2016). Polskie gospodarstwa roślinne na tle gospodarstw wybranych krajów. Zagadnienia Ekonomiki Rolnej, no. 2(347), pp. 73-94. 
JAN PAWLAK

Instytut Technologiczno-Przyrodniczy

Oddział w Warszawie

\title{
WYPOSAŻENIE W SIŁĘ POCIĄGOWĄ A WYDAJNOŚĆ PRACY W POLSKIM ROLNICTWIE
}

\begin{abstract}
Abstrakt
$W$ artykule przedstawiono analize współzależności między stanem siły pociagowej a wydajnościa pracy w rolnictwie. W latach 1950-2010 zasoby sity pociagowej (żywej i mechanicznej) w rolnictwie polskim zwiększyty sie o 365,7\%, w tym mechanicznej 65-krotnie. W tym samym czasie liczba pracujacych $w$ rolnictwie polskim zmniejszyła się o ponad 37\%, zwiększyła się natomiast wartość produkcji rolniczej $w$ cenach stałych, $w$ tym: globalnej o 98\%, końcowej - o 156\%, a towarowej - o 280\%. Wydajność pracy $w$ rolnictwie, mierzona wartościa produkcji $w$ cenach stałych $w$ przeliczeniu na osobe pracujaca, zwiększyta się w przypadku przyjęcia za miernik tej produkcji: produkcji globalnej-o $216 \%$, produkcji końcowej-o 305\%, a produkcji towarowej - o 506\%. Stwierdzono silnie zaznaczona dodatnia współzależność między wyposażeniem w sitę pociagowa a wydajnościa pracy $w$ rolnictwie. Siła tej wspótzależności stabnie w miarę zwiększania stanu wyposażenia rolnictwa $w$ siłe pociagowa.
\end{abstract}

Słowa kluczowe: wydajność pracy, stan siły pociągowej, współzależność, rolnictwo.

Accepted for print: 16.10 .2017$.

Unless stated otherwise all the materials on the website are available under the Creative Commons Attribution 3.0 Poland license. Some rights reserved to the Institute of Agricultural and Food Economics - National Research Institute.

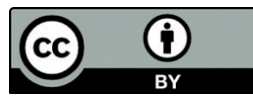

